\title{
Nyaars-Morgen - historie, fornyelse og fallesskab
}

\author{
Af Marie Louise Nyegaard
}

Med afsæt i et nyvundet håb for sin egen og sit lands fremtid skriver N. F. S. Grundtvig i 1824 digtet Nyaars-Morgen. Som Sune Auken påpeger, er Grundtvig i denne periode optaget af at få fortiden til at tale ind i nutiden og af sammentænkningen af mytologi, historie og kristendom. Historien anskuer Grundtvig som en strøm, der som et hav spejler himmelen. Denne spejlingstanke udtrykker Grundtvigs typologiske historiesyn.

Nyaars-Morgen udfolder, hvordan Grundtvig ser det som et kald at føre Norden frem til den rette historiebevidsthed og dermed muliggøre en åndelig fornyelse. Digtet er stærkt præget af selvsymbolik, det er en myte om Grundtvig selv som poet, profet og vækker af den nordiske folkeånd under indflydelse af Helligånden. Digtets ti sange rummer et omfattende billedsprogligt univers og viser vejen til fornyelsens morgengry som en trinvis udvikling frem mod en fælles og folkelig bevidsthed om den nordiske fortid. Indholdet og strukturen i det lange komplicerede digt ridses op og herigennem vises, hvilke tanker der gjorde sig gældende i Grundtvigs digtning $\mathrm{i}$ året op til den kirkelige anskuelse.

Sune Aukens disputats Sagas spejl. Mytologi, historie og kristendom hos N. F. S. Grundtvig fra 2005 er en inspirerende indgangsvinkel til læsning af Grundtvigs digtning. Værket er til stor gavn og brug for den, der ønsker at have en ledsager med på rejsen ind i Grundtvigs poetiske univers. ${ }^{1}$ Det følgende er et eksempel på en sådan rejse - en rejse ind i Grundtvigs "store, underlige Nyaarsmorgen-Drøm", som B. S. Ingemann poetisk beskrev digtet Nyaars-Morgen fra $1824 .^{2}$

Aukens analyse af dette digt udmærker sig ved at være baseret på en helhedsforståelse ud fra et blik for digtets indre struktur. Det er den første samlede litterære analyse af digtet og sammenknytter mange af de tråde, som forskerne Holger Begtrup, Helge Toldberg, Jacob Balling, Flemming Lundgreen-Nielsen og andre tidligere har udstukket. Samtidigt har Auken et imponerende overblik over den kontekst og de forudsætninger ved Grundtvigs tænkning, der er afgørende at holde sig for øje, når man vover sig ind i værket.

Præmisserne for Nyaars-Morgen er således en forståelse af den sammentænkning af mytologi, historie og kristendom, der gør sig gældende for Grundtvig i 1824. 


\section{Mytologi}

Sune Auken diskuterer indgående den omorientering, han mener finder sted i Grundtvigs historiesyn fra 1815. Han beskriver, hvordan mytologien helt forsvinder fra Grundtvigs poetiske billedunivers efter sammenbruddet i 1810-11. Dette sker som en følge af det selvopgør, Grundtvig foretager med den person, han var, da han skrev Nordens Mytologi i 1808. Aukens antagelse er, at mytologien var blevet et selvforløsende system - en teologi for Grundtvig, og at han derfor så sig nødsaget til at vende sig fuldstændigt bort fra en eksistensforståelse, der nær var ved at lede ham til kætteri.

Mytologiens forsvinden og genopdukken kan naturligvis diskuteres. Grundtvig går i årene mellem $1810 \mathrm{og} 1815 \mathrm{i}$ gang med at oversætte Snorres Norske Kongekrønike (Heimskringla), og digtet Roskilde-Riim, der udkom i 1814, har også enkelte referencer til den nordiske mytologi. Vigtigst i denne sammenhæng er dog, at da mytologiens og romantikkens virkemidler atter ses i Grundtvigs digtning fra 1815, er det under ændrede forudsætninger. Mytologien er ikke længere eksistensforståelse og helhedstolkning, men en del af den værdifulde danske arv, der peger frem mod kristendommen. Auken påpeger, at hvor mytologien tidligere var teologi, bliver den nu antropologi, idet den udsiger noget vigtigt om det nordiske folk før kristendommens indførsel. Nordens fortid rummer tegn, der peger frem mod en storslået fremtid. Grundtvig anser myterne som en værdifuld arv. De er en del af historiens strøm, men det er nu tydeligt, at kristendommen indtager pladsen som den afgørende livstydning. Derfor kan han i Et Blad af Jyllands Rimkrønike fra 1815 skrive således:

Ja, ton min Sang fra Først til Sidst

Til Priis for Gud alene!

Ja, Tant er uden Troe paa Christ

Alt Syn paa Runestene,

Og Tant er hvert et Skialdesyn,

Der ikke slaaer som Himmellyn

Det fromme Christen-Hierte.

(US III, 247)

Runestenene er et billede på mytologien, der kun kan bidrage med værdifuldt materiale, hvor den anvendes $\mathrm{i}$ en overordnet kristen livstydning. Ellers ender man i "Tant", som Grundtvig selv var på nippet til i 1810 med, hvad han også selv omtalte som sit hedenske kætteri (US IV, 232). 


\section{Historie - spejl og typologi}

Denne omorientering i synet på mytologiens rolle og fortidens betydning tematiseres i det store komplicerede digt Nyaars-Morgen. For at kaste lys over, hvad der er på spil i digtet, kan det være gavnligt med en nærmere undersøgelse af Grundtvigs ændrede historiesyn, der kan belyses ved hjælp af hans brug af spejlet som metafor.

Brugen af spejlmetafor dukker første gang op i Verdens Krønike fra 1814 , hvor Grundtvig knytter an ved sætningen, at vi endnu ser " $\mathrm{i}$ et spejl, i en gåde" fra 1 Kor 13. Han anvender billedet på historien forstået på den måde, at Danmarks historie taler et guddommeligt sprog, fordi det himmelske spejler sig i historien. Historiesynet bliver her typologisk, således at historiske begivenheder spejler hinanden og tilsammen kan være henpegende på noget fremtidigt. På denne måde er den nordiske mytologi ikke længere et selvforløsende system for Grundtvig, som den var i 1808, men en præfiguration for kristendommen. Danmarks hedenske fortid er en figur eller type, der peger frem mod den kristne nutid og videre mod en storslået fremtid. Anvendt i denne kontekst bliver mytologien et vigtigt erkendelsesmateriale.

Spejlingens forudsætning er det guddommelige. Det guddommelige sætter mennesket i stand til at opnå indsigt i det evige. Det er dog alene forbeholdt Gud at have absolut indsigt i historiens og kristendommens sammenhænge. Menneskets adgang til det guddommelige har at gøre med det vigtige begrebspar syn og sang, forstået som visionær og sproglig formidling. Ordet, det Levende Ord, er således den gudgivne mulighed for, at mennesket kan være i kontakt med Gud, fordi Ordet bibringer en vekselvirkning mellem Gud, der skaber og handler med sit ord, og mennesket, der svarer tilbage. Således rummer Ordet og dermed billedsproget Guds nærvær. Ligesom Helligånden i Grundtvigs forståelse er til stede i Det Levende Ord.

\section{Kristendom}

Du Soel under Dække,

Lys-Billed af Ham,

Der lod sig paalægge

Vort Aag og vor Skam, (str. 11)

Sigtet med Nyaars-Morgen er foreningen mellem historie og kristendom, mellem himmel og jord og mellem Gud og menneske. Inkarnationen er for Grundtvig en del af historiesynet og muliggør det typologiske perspektiv, således at havet som symbol på historien udgør 
en spejling af himmelen, det sted, hvor solen bryder frem (Auken 2005, 393). Fordi Kristus har overvundet døden, kan mennesket se Guds handlen i verden. Solen, der stråler over den nordiske verden, optræder som et billede på Kristus, den bagvedliggende forudsætning for alt, hvad digtet udfolder.

Inkarnationen er forudsætningen for livets sejr over døden, og samtidigt er det inkarnationen, der muliggør spejlingstanken. NyaarsMorgen kan derfor siges at have Kristi opstandelse som bærende princip. Solen som metafor for Kristus understreger forbindelsen mellem menneskets verden og det guddommelige. Digteren er sig tydeligt denne forbindelse bevidst; "Om Soel vilde gjemme / Lidt Guld i min Mund" (str. 6). Hans opgave som skjald og folkeåndens opvækker muliggøres af det guddommelige, der lægger Guld i hans mund, så han kan tale sandt om det åndelige.

Alt har en indre sammenhæng i Grundtvigs tænkning. Historiske begivenheder peger mod hinanden, himmelen spejler sig i tidens strøm, i naturen og i menneskeøjet. Spejlmetaforen i Grundtvigs digtning er således kendetegnet ved det henpegende aspekt, men også af en tanke om vækst. Kristendommen opfylder og overgår det hedenske. Sammenstillingen af henpegen og vækst er som bekendt et tilbagevendende og grundlæggende element i Grundtvigs tænkning.

Med en fornyet og afbalanceret sammentolkning af mytologi, historie og kristendom kan Grundtvig nu tage rollen op som fornyer af den danske folkeånd ved hjælp af sit syn og sin sang.

\section{Indblik-Et kig ind i Nyaars-Morgen}

Med sine 312 strofer udfolder Nyaars-Morgen en sand overflod af metaforsværme i en kompleks struktur, der tidsmæssigt bevæger sig frem og tilbage i Danmarks historie og i digterens egen selvbiografi. ${ }^{4}$ Det grundlæggende tema i digtet kan opsummeres som Grundtvigs håb om en storslået fremtid og åndelig genoprejsning af Norden. NyaarsMorgen udfolder digterens profetiske håb om en nybrudstid funderet $\mathrm{i}$ en fremdragelse af den nordiske arv og tradition med sig selv i rollen som vækker og forener af folket. Grundtvig ser sig kaldet af Helligånden til som poet og profet at opvække folkesjælen ved at forkynde de syner, han har modtaget.

\section{Højdepunktet}

1. sang: Nyaars-Morgen tager sin begyndelse ved højdepunktet - og således ved målet for de resterende sange - ved at beskrive en dennesidig paradisisk tilstand, udtrykt $\mathrm{i}$ en rolig, varm morgenscene i en nordisk natur. Over denne fredelige og harmoniske verden lyses et 
"Guds Fred og God-Morgen!"' (str. 3). Hermed er endemålet for digtets handling udstukket fra begyndelsen. Læseren præsenteres for den sfære, digtet indbefatter, for en nordisk verden, hvor havet, naturen og digterens røst tiljubler solens sejr over mørket. En verden, hvor en kamp af apokalyptiske dimensioner mellem dag og nat for nylig har stået på:

At Natten er svundet,

Med Skyggernes Hær,

Og Solen oprundet

Til heltelig Færd

(str. 7)

Den forudgående natlige kamp udfoldes i de følgende otte sange, der former sig dels som et selvmytologisk tilbageblik på Grundtvigs egen livsbane i årene 1806-24, dels som en rejse i Danmarks historie.

\section{Mytologiens rolle}

2. sang leder os dermed tilbage til det første minde, digteren ønsker at fremføre. Et tilbageblik på den tid, hvor Grundtvig gennemlevede sin asarus. Sangen foregår i vinterkulde og nattemørke og står i total modsætning til digtets første sang.

Jeg drømde, at, slaget

Af Marken, paa Fjeld,

Af Lykken bedraget,

Jeg vanked i Kveld,

Bortblæst var min Størke,

Og myrdet min Ro,

Med Rædsel, i Mørke,

Jeg savned min Tro,

Mit Hjertes Veninde,

Som gik mig af Minde

I Hjerne-Vildfarelsens Aar!

(str. 22)

Kontrasten mellem første og anden sang er slående. Digtets 2. sang former sig som en drøm, hvori digteren i en tilstand af rædsel og mangel på styrke, lykke og tro foretager en rejse til fortiden i følgeskab med Odin (str. 24). Ridende på den mytologiske hest Sleipner rejser de over de blå bølger. Rejsen er en efterklang af Saxos fortælling om, hvordan Hading, inden han bliver Danmarks konge, indbydes til at rejse over havet med guden Odin.

Sangen udfolder en desperat søgen efter et troens holdepunkt. Man fornemmer forvirring og skyggespil (str. 36). Der findes dog sandhed gemt $\mathrm{i}$ fortidens hedenske skygger, men digteren når til den erkendelse, at de ikke alene kan gøre det ud for en eksistensforståelse. 
Denne erkendelse er den første forudsætning, der skal på plads forud for den nye morgens gennembrud.

\section{Den kristne tro}

3. sang: Næste minde er overgangen mellem, hvad digteren selv betegner som sin henholdsvis "Mytologiske" og "Theologiske" periode (US IV, 232). Han bevæger sig her fra drøm til vågen tilstand, og mytologien er nu aldeles fraværende. Til gengæld fremkommer en sværm af kristne referencer. Digteren ser tilbage på sit tankesystem fra før 1810-11 og forstår nu, at det var et lys uden varme. Som en anden Martin Luther forsøger han nu ved egen kraft at kæmpe sig til frelsen: "Jeg kæmpe mig vilde / Til Kjærligheds-Kilde, / Omskabe jeg vilde mig selv!" (str. 41). På dette kritiske sted træder Helligånden personificeret ind på digtets scene. Ånden taler direkte til digteren med en kraftig irettesættelse af hans forsøg på selv at komme frelsen nærmere. Her sker et afgørende skifte, hvor troen kommer ham i møde, og han lader sig døbe af Ånden. Med dåben pålægges han en profetisk kaldelse, han skal forkynde og oplyse om, hvad Ånden har vist ham:

Udraab hvad du skuer!

Fortæl hvad du veed!

(str. 51)

Denne opgave til trods er han endnu meget langt fra fuldendelsen, dog har han nu for læseren slået fast, at han har såvel Odins som Helligåndens autoritet med sig (Auken 2005, 387). Selvom det, han forkynder, virker dunkelt og sært, kan han ikke gøre andet end at formidle de syn, han får. ${ }^{5}$ Det viser sig, at hans syn både peger mod en kristen fremtid og mod Nordens fortid.

\section{“Gak ud, og tie stille for Gud!"}

I 1815 blev Grundtvig udsat for en voldsom kritik af sit historiesyn og sin bibeltro lutherske teologi, og da ingen vil tage imod hans budskab, beslutter han som bekendt helt at opgive rollen som prædikant. Modstanden bliver i den selvmyte, Nyaars-Morgen udfolder, et nederlag pålagt af Helligånden. I Grundtvigs mytologiske selvforståelse bliver opgivelsen af præstegerningen en nødvendighed, der tillægges en indre sammenhæng med hele hans livsbane.

4. sang: Igen anklages han af Ånden, der denne gang kommer ham i møde i en dues skikkelse, for at have været for voldsom og for tidligt ude i sin kamp for kristendommen (str. 77-80). Digteren erkender at have fejlet, men tager samtidigt til genmæle mod Åndens anklager: "Vist haver jeg feilet, / I Skjøn, som i Skud / Dog altid i Speilet / Jeg ledte om Gud" (str. 93). Digteren erkender sin menneskelige svaghed 
og fejlbarlighed - men minder også om, at det netop var for det fejlbarlige menneske, Frelseren gav sit liv.

Efterfølgende modtager han en fjer af duens vinge som et tegn på, at det er igennem digtningen, han skal udfolde Åndens budskab. Trods denne gave og opgave afsluttes sangen med en konstatering af, at det stadig er midvinter og nat i Norden. Vinteren er selve Fimbulvinteren, varslet om Ragnarok, og hermed har digtet nået et absolut lavpunkt. Den nedadgående udviklingskurve, der blev indvarslet i 2. sang, er endnu ikke knækket.

\section{Historien som en frit flydende strøm}

5. sang: I den tunge ragnaroksstemning fra 4. sang bevæger digtet sig nu i en sælsom retning. Nok en gang indbydes digteren til at foretage en rejse med Odin hen over tidens strøm tilbage til Nordens oldtid. Odin viser digteren: "At Himlen i Vove / Dog haver et Speil" (str. 101). Det himmelske spejler sig i voven - tidens strøm. Mytologien placeres som en del af historiens hav, nemlig det hav, kristendommen spejler sig i.

Tilbage i mytologiens hal kommer en kvindeskikkelse digteren $\mathrm{i}$ møde. Skikkelsen er Vor Moder, den personificerede Danmarkshistorie. Med Vor Moder bringes det første anstrøg af ægte varme ind i digtet. Hun er levende krop og ånd. De to drager sammen til det sted, hvor hendes vugge er placeret, til De Levendes Land. Vuggen ser Auken som et billede på historiens udspring, og vi befinder os således tidsmæssigt forud for mytologien.

Vejen til Vor Moders vugge er imidlertid spærret af en mur af is. Historien forhindres $\mathrm{i}$ at strømme frit, og dette er årsagen til, at den nordiske verden henligger i mørke og kulde. Foran ismuren udspiller der sig nu en mærkværdig scene, hvor Vor Moder kaster en død hane over på den anden side. Hanen vækkes til live, og denne overvindelse af døden făr ismuren ind til Danmarkshistoriens vugge til at smelte, og den nordiske verden vækkes atter til live.

Vi ser her et avanceret billede på, at gennem døden skal livet genvindes (Auken 2005, 405). Grundtvig formår nu at anvende mytologien som et grundlag for kristne associationer, og hermed er den typologiske tænkning omsider ved at falde på plads i digtet.

Et stærkt symbol i denne sang er i øvrigt Kærmindeblomsterne. En vigtig metafor, der i Grundtvigs digtning er endnu en variation over spejlingsmotivet. Kærmindeblomsten er for Grundtvig en typisk dansk blomst, almindelig og jævn som påskeliljen. I blomstens navn ligger betydning "kærlige minder", og dens farve er blå, himmelens, havets og øjets farve i Grundtvigs symbolverden (Toldberg 1950, 44-46). Således har kærmindeblomsten også et spejlingselement, idet dens 
farve spejler himmelen. Symbolet rummer såvel en sproglig side - det kærlige minde - som en visuel $\mathrm{i}$ den blå farve. Blomsten er Vor Moders (og havfruens) attribut. Vor Moder sammenføjet med kærmindeblomsten udgør et symbol på det kristne Danmark, på landets historie sammenføjet med himmelspejlet.

\section{Skjaldens selvoffer}

6. sang: Efter den mytiske tidsrejse vender digtet atter tilbage til Grundtvigs egen livsbane, til årene med de store oversættelser. Digteren har nu set en lignelse om, hvordan kulden og mørket skal overvindes ved at skabe adgang til historiens strøm, men realiseringen viser sig imidlertid at være nær umulig. For på trods af Grundtvigs anstrengelser for at bringe Nordens oldtid til folkets bevidsthed er der ingen, der vil tage imod hans arbejde og budskab. "Jeg talde tilsidst med mig selv!" (str. 158)

Det går op for ham, at han selv må spille hanens rolle for at genskabe forbindelsen til den historiske arv. Den død, som Vor Moder viste ham i 5. sang, må han selv personligt stå igennem. "Jeg maatte da føie / Vor Moder, og døe" (str. 159). Via overvindelsen af døden bliver den sande verden og det sande menneskelige fællesskab muligt (Balling 1998, 123).

Paa Trods mod Naturen,

Til Gavn for de Smaa, Jeg maatte ved Muren

Som hovedløs staae,

Mens Hoved fra Hærde

Fløi lukt over Gjærde,

Thi selv gik for Hane jeg her!

(str. 160)

Gennem sin selvofring indoptager Grundtvig folket, mytologien, lutherdommen og historien i sin egen person. Flemming LundgreenNielsen beskriver således handlingen som højdepunktet for Grundtvigs selvsymbolik. Grundtvig er muligvis selv bevidst om dette. I den ene strofe sætter han sin egen person i relation til Kristi overvindelse af døden, men vender sig i den næste til et pludseligt angreb på samtidens lærde i, hvad der må opfattes som et apologetisk forsvar for sin egen rolle.

Sangens sidste strofe afslører, at vejen gennem døden har betydet en genoprettelse af forbindelsen mellem nutid og fortid: "Hvor Skyggerne tale / Om Thyra i Dvale, / Kjærminder om Livet i Løn!" (str. 168). Skyggerne, mødet mellem lys og mørke, er et billede, der her svarer til gådespejlet og viser noget om Danmarks fortid. ${ }^{6}$ Kærmindeblomsterne fortæller om det skjulte liv, nemlig livet i det hinsides. Den 
typologiske tænkning kundgøres nu også i naturen. Med 5. og 6. sang er udviklingen i digtet omsider på vej opad i en positiv retning, hvor forudsætningerne for et åndeligt gennembrud er ved at falde på plads.

\section{Folkets røst}

7. sang: Med naturens medleven indfinder der sig endnu et gennembrud i digtet. Der lyder nu en "folkelig Røst". Auken påpeger, at røsten er lig folket, den omfatter det og er essensen af det (Auken 2005, 418). Danmarkshistoriens stemme indeholder oldtidens sang, Kingos digtning, fædrenes salmer etc. Det danske sprog er et symbol på det nationale fællesskab, ligesom det er historiens sprog. Hvis det skal lykkes at genoplive folkearven gennem digtningen, må det foregå på et sprog, der er folkets og folkearvens tungemål.

Digtets længste sang kredser i en vekslen mellem håb og frygt om, hvordan digteren skal formidle gennembruddet til folket. Først da han erkender, at det er ud fra sin egen ånd, han kan kaste lys over historien og bringe Vor Moder til live, når han et positivt vendepunkt. Pointen er her, at det er digterens egen handlen, der fører til, at historien kan sende sine stråler over folket, og dermed kastes også lys ind i selve digtet. Som hos en profet sker alting gennem digterens egen person, selvom det ikke er under hans egen kontrol. Han har på egen hånd måttet finde de rette forudsætninger i form af den kristne tro, pennen og billedsproget, men da disse elementer er på plads, kommer morgenrøden ham i møde: "Da saae jeg Dag-Røde, / Fra himmelblaa Strand" (str. 219).

\section{Fællesskabet}

8. sang uddyber på én gang opdagelsen af fællesskabet og Grundtvigs begejstring for B. S. Ingemanns episke digtning Valdemar den Store. Ingemann skrev digtet på baggrund af Grundtvigs Saxo-oversættelse. Det fremgår af brevvekslingen mellem de to venner og digtere i 1824, at Grundtvig var skeptisk over for Ingemanns fremstilling af Saxo som en "aandløs og kejtet Bogorm". For Grundtvig var Saxo "Faderen for al ægte dansk poetisk-historisk Videnskabelighed", og han følte sig derfor selv som en genlyd af ham (Grundtvig 1882, 17-18). På trods af denne uoverensstemmelse i synet på Saxo glædes Grundtvig alligevel over, at han nu ikke længere er alene i sin kamp for at bringe Nordens fortid til live. Ingemann optræder således i sangen i skikkelse af en svale (str. 230 ff.) - et genkendeligt tegn på forår og sommer. Grundtvig finder i mødet med Ingemanns digt omsider en vej ud af sin isolation og en vej ud af angsten for mødet med samtidens ligegyldighed, som han gennem størstedelen af digtet har vaklet under. Derfor kan han i strofe 232 i triumferende tonefald udbryde: "Ja, nu 
faae vi Sommer, / Og nu har vi Dag". Den ensomme digter og profet kan med sit "nu" og sit "vi" forvisse sig om, at håbet for Norden vil sejre og endda tale om gennembruddet i nutid.

Følelsen af fællesskab leder naturligt over i dåbs- og nadverbilleder. Digteren konstaterer nu, at Gud ser Danmark. Ja, Grundtvig sammenfletter ligefrem Danmarks historie med den bibelske historie Vor Moder med Noa (str. $250 \mathrm{ff}$.) - i et kompliceret billede af Vor Moder som en datter af Noa, der får vinger og flyver ud for at finde sit hjem i det sjællandske landskab, hvor himmel og hav mødes.

\section{Modtagelse eller ligegyldighed?}

9. sang: Selv efter opdagelsen af fællesskabet, naturens medleven og den typologiske sammenhæng er der stadig plads for stor usikkerhed i digtets næstsidste sang. Digteren frygter, at folket ikke vil tage imod hans budskab og acceptere sig som en del af historiens strøm. Hvis ingen vil modtage hans budskab, har kampen været forgæves. Derfor overvejer han at udvandre fra landet og tage folkeånden med sig. Han har altså på dette sted fuldstændigt identificeret Danmarks historie med sin egen person. Først da han erindrer sig sin gamle barnepige Malene ("Gold-Ammen") og den måde, hun førte fortidens guld videre gennem sine fortællinger, føler han sig forpligtet til at blive i Danmark (str. 285 ff.). Den folkelige sprogskat har digteren båret med sig, og erindringen om Vor Moders røst, der har overlevet hos det jævne folk, overbeviser digteren om, at han skal blive i Danmark (str. 293). Vor Moder taler nu direkte til folket gennem ham, og digtets retoriske formål understreges hermed.

\section{Se, jeg gor alting nyt}

10. sang: Finalen er en tilbagevenden til digtets begyndelse. Betydningen af 1 . sang træder tydeligt frem for læseren, der nu har gennemlevet nattens kamp i følgeskab med digteren. På den baggrund triumferer håbet, og morgengryet sejrer. Guds Fred lyses atter over hele den nordiske verden, en fred, der indbefatter fortid, nutid og fremtid:

Guds Fred, som den fandtes

Ved Fædrenes Barm!

Guds Fred, som den vandtes

Ved Frelserens Arm!

Guds Fred, som den throner,

Hvor Kjærlighed boer!

Guds Fred, som den toner

I Hytter af Jord,

Som selv jeg den nyder,

Jeg ønsker og byder 
Nu Brødre og Frænder i Nord!

(str. 298)

Digtet afsluttes med endnu en understregning af, at digteren ikke taler ud af egen fantasi - han formidler blot de syner, Ånden har skænket ham. Opfyldelsen af digtets vision ligger endnu i fremtiden, som titlen implicit antyder. Fremtidsaspektet understreges yderligere af Åndens lange afsluttende tale, en profeti om, hvad det er, forløbet i NyaarsMorgen har forberedt (Auken 2005, 455). Finalen rummer således en begyndelse, ligesom morgenen er dagens begyndelse, og nytåret er årets.

\section{Overvejelser}

Gennem analysen af Nyaars-Morgen kan uddrages en række aspekter af Grundtvigs tænkning i 1824. Grundtvig oplever et brud mellem den faktiske verden, der omgiver ham, og den ideale verden, han ønsker at bringe frem. Ligeledes erfarer han et voldsomt skel mellem sin opfattelse af sig selv som profet og fornyer på den ene side og samtidens ligegyldighed over for hans person på den anden. Skellet medvirker til, at han føler sig ensom og isoleret. Digtet er en afspejling af Grundtvigs splittelse mellem håb og fortvivlelse. Ved at lade Nordens historie følge sit eget livsforløb viser Grundtvig, hvordan hans person har en særlig betydning for en åndelig genrejsning af Norden. Med udgangspunkt $\mathrm{i}$ en morgenverden $\mathrm{i}$ ordnet harmoni danner digtet en bue over historien og digterens eget liv, der sigter mod en ny harmonisk tilstand i digtets sidste sang. Grundtvig lader alting pege frem mod idealverdenens gennembrud, så alt det gamle bliver nyt. Helge Toldberg karakteriserer digtet som Grundtvigs egen myte indfældet $i$ en udefrakommende demonstration af livets og lysets sejr, en sejr af Guds nåde (Toldberg 1950, 88).

Nyaars-Morgen er som helhed ét langt argument for at få folket til at indoptage spejlingstanken som verdenstolkning og dermed anerkende, at historiens strøm har en retning, som folket selv er en del af. I Grundtvigs forståelse udgør historien en strøm, der afslører en sammenhæng mellem begivenheder, og på samme måde er mennesket grundlæggende forbundet med historicitet. Mennesket er sat i verden og dermed i historien, så for at forstå sig selv må mennesket forholde sig til fortiden og til sig selv. Mennesket er selv en del af spejlingen. Det himmelske, der spejler sig i menneskets øje, er både en antydning af Grundtvigs syn på typologi og på forholdet mellem Gud og menneske. At himmelen lader sig spejle i menneskets øje, viser os, at mennesket er det sted, hvor det himmelske og det jordiske kan mødes. 
Mennesket fremstår, som Balling har udtrykt det, som et prisme, hvori helheden mødes og brydes (Balling 1999, 26).

Derfor er det afgørende for Grundtvig at fă fortiden til at tale ind i nutiden. Man fornemmer tydeligt hans frustration over samtiden, som i hans opfattelse er præget af ligegyldighed over for fortidens betydning for nutiden. Samtidens ligegyldighed er motivationen for, at han via syn og sang vil forsøge at skabe balance mellem mytologi, historie og kristendom.

I Nyaars-Morgen har de nordiske myter ikke alene deres eget indhold, de er også præfigurationer på noget større, nemlig kristendommen. Grundtvig ser altså myterne som realprofeti på kristendommen. Mytologi og kristendom peger dermed på hinanden og danner tilsammen en forventning om en storslået fremtidig opfyldelse. $^{7}$

Digtet Nyaars-Morgen er på mange måde et uhåndgribeligt værk. Det indeholder en for læseren uoverskuelig sværm af metaforer, mytologiske skikkelser, bibelske referencer og selvbiografiske detaljer. Hele denne mangfoldighed har dog en klar retning frem mod morgengryets gennembrud i 10. sang. Bibelen læst som en samlet fortælling udgøres af en v-formet udviklingskurve forstået på den måde, at udgangspunktet er den perfekte tilstand ved skabelsen, og slutpunktet er genoprettelsen af menneskets sande gudsforhold. Herimellem sker der først en nedadgående og derefter opadgående udvikling. Johannesåbenbaringens "Se, jeg gør alting nyt" $(21,5)$ bliver dermed alle antitypers antitype og selve opfyldelsen af Bibelens første ord. Det samme kan siges at gøre sig gældende i Nyaars-Morgen. Digtet begynder og slutter ved højdepunktet. Derimellem sker først en nedadgående og derefter en opadgående bevægelse imellem yderpunkterne ro - uro - ro.

Digtet har et mål, som hver enkelt sang udvikler sig hen imod. På vejen skal forhindringer fjernes, og de rette forudsætninger skabes. De ti sange forholder sig til hinanden som en trinvis udvikling frem mod den harmoniske morgenverdens gennembrud. Sune Auken gør opmærksom på, at hver sang repræsenterer noget nyt i forhold til den foregående, men at der aldrig finder en fuldendelse sted inden for én sang $(2000,45 \& 2005,300)$. På den måde peger hver enkelt sang frem mod den næste, og alle danner tilsammen en helhed. Et karakteristisk træk ved digtet er således, at ingen af sangene afsluttes i perfekt harmoni. Der sker en trinvis opnåelse af forudsætningerne for gennembruddet, men hver gang et nyt punkt er nået, viser der sig endnu en problemstilling - ofte værre end den foregående.

Dette karaktertræk ved digtet afspejler på elegant vis menneskets verden. Mennesket lever netop underlagt det grundvilkår, at selvom 
døden én gang for alle er overvundet ved Kristi opstandelse, så er synden og ondskaben stadig i verden. Det ufuldendte skaber en modvægt til det Kristusbillede, som digtet udfolder - billedet af den sejrende, ophøjede Kristus, hvis menneskelige natur ikke spiller nogen rolle. Kristus optræder som den livgivende sol, der sejrer over mørket, og billedet kan give indtryk af, at den yderste dag og dommen over synden er uden betydning. Nyaars-Morgen udfolder dog en velkendt spænding mellem et allerede og et endnu ikke. Døden er allerede overvundet, men Gudsriget er endnu ikke realiseret.

Her modsvares spændingsfeltet af afstanden og nærværet, der gør sig gældende i forholdet mellem Gud og menneske. Mennesket er skabt i Guds billede, men samtidigt faldet. Erindringen om, at mennesket er skabt i Guds billede, lever både i Gud og menneske. For mennesket er håbet derfor af afgørende betydning. Håbet kommer med Kristus, der genopretter vejen til Paradiset og skal modtages i troen. Landets historie, folket, det enkelte menneske og frem for alt Grundtvigs egen livsbane skal pege mod fuldendelsen. Historien er en strøm, der flyder fra skabelsen og til fuldendelsen.

Teologisk betragtet udfolder Nyaars-Morgen Grundtvigs trinitetsteologi. Gud, Søn og Helligånd fremstår i digtet som den overordnede guddommelige treklang. Gud er skabelsens og opretholdelsens Gud, fra hvem Sønnen og Ånden udgår. Gud er den samme Gud fra skabelsen til fuldendelsen, og han handler i historien. Inkarnationsteologien er, som nævnt, markant i digtet, med den sejrende Kristus strålende på himmelen som den livgivende sol. Kristus er lyset, der skænker mennesket, den kristne (her Grundtvig), indsigt i, at Gud handler i verden ved at lade historien have en bestemt retning frem mod fuldendelsen. Helligånden spiller, som vi har set, en fremtrædende rolle i Grundtvigs teologi. I digtet optræder Ånden som et personificeret nærvær, der meddeler sig til digteren og giver ham instrukser om, hvad han skal gøre.

\section{Udblik}

Med Nyaars-Morgen viser Grundtvig sit blik for, hvordan naturen, myterne, historien og den opstandne Frelser er det, vi har tilfælles med de generationer, der er gået forud. Linjen binder de kristne sammen gennem alle tider i historiens strøm og ikke kun gennem Bibelen. Grundtvig fokuserer på kirken som et samfund af troende, idet han lægger vægt på menneske, fællesskab og historisk bevidsthed. Fællesskabet mellem de kristne gennem alle tider mærkes kun gennem historien. Toldberg finder i tråd med dette, at der bag den såkaldt mageløse opdagelse sker en overgang i Grundtvigs tænkning til et 
evangelium, der er enklere end det bibelske. Bibelen er således suppleringer og udfoldelser af det kristne budskab, hvorimod trosbekendelsen er det absolut forpligtende grundlag, den kristne døbes på, og stedet, hvor Gud taler til mennesket.

Grundtvig når i Kirkens Gienmcele fra 1825 frem til en forståelse af trosbekendelsen som kirkens grundlag. Trosbekendelsen er det igennem alle tider grundlæggende, uforanderlige samlingspunkt for kirken og dens menighed. Han hæfter sig ved, at der har der været kristne før Bibelen, og at den kan derfor ikke være kirkens klippe. Fortid og nutid må stå i det rette forhold, hvis kirken skal være nærværende og gyldig. Kirken var til før Bibelen, og det er en selvfølge, at kirken hviler på et historisk fundament (US IV, 403).

Ligesom folket i almindelighed må have fortiden levende til stede for at erkende nutiden, således må også de kristnes trossamfund bevare forbindelsen til historien, der ifølge Grundtvig er den eneste vej tilbage til den levende Jesus: "vil vi have Grund til at troe, maae vi altsaa vende tilbage til Historien: betragte Evangelierne og Apostlernes Gierninger som en sand Historie, der viser, at Jesus er værd at troe paa, og Apostlerne hans Aands Vidner, hvis Oplysning om de aandelige Ting er troværdig" (US IV, 413).

Selvom Grundtvigs tanker om trosbekendelsens betydning ikke direkte tematiseres i Nyaars-Morgen kan der drages flere paralleller mellem det tankesæt, digtet udfolder, og de pointer, han fremlægger i Kirkens Gienmoele. Digtet udtrykker Grundtvigs søgen efter den sande tro og det rette forhold mellem historie og kristendom. Et forhold, han netop ikke baserer på Bibelen, men på Ordet, symbolet på forbindelsen mellem Gud og menneske. Tanken om det talte ords betydning er således allerede på plads i Nyaars-Morgen, og den mageløse opdagelse kan derfor siges at være velforberedt og gennemtænkt i Grundtvigs digtning.

Der er altså en linje i Grundtvigs tænkning og digtning fra hans syn på sig selv som skjald og seer og dermed profet til hans betragtning af Ordet som legemliggørelsen af Ånden - først i billedsproget og senere i det talte ord. Disse tråde fører endelig frem til udviklingen af det nye syn på kirkens fundament i 1825, nemlig i en fremhævelse af den talte trosbekendelse frem for den skrevne Bibel.

\section{Forkortelser}

PS I-IX: Svend Grundtvig et al. (udg.) (1880-1930), N. F. S. Grundtvigs Poetiske Skrifter, bind 1-9, København.

US I-X: Holger Begtrup (udg.) (1904-09), Nik. Fred. Sev. Grundtvigs Udvalgte Skrifter, bind 1-10, København. 


\section{Litteraturliste}

\section{Værker af Grundtvig}

Grundtvig, N. F. S. (1816), "Et Blad af Jyllands Rimkrønike" i US III, 196-247.

_ (1824), Fortale til "Nyaars-Morgen. Et Rim" i US IV, 237-248.

— (1824), "Nyaars-Morgen. Et Rim" i US IV, 249-343.

(1824), "Brevvexling mellem Nørrejylland og Christianshavn" i US IV, 228-236.

— (1825), "Kirkens Gienmæle" i US IV, 396-429.

Grundtvig, Svend (red.) (1882), Grundtvig og Ingemann. Brevvexling 1821-1859, København.

— et al. (udg.) (1883), N. F. S. Grundtvigs Poetiske Skrifter, bind 5, København.

\section{Værker af andre forfattere:}

Auken, Sune (2000), "At Himlen i Vove dog Haver et Speil. Udkast til en figural læsning af Grundtvigs Nyaars-Morgen" i Transfiguration 2, København, 43-57.

- (2005), Sagas spejl Mytologi, historie og kristendom hos N. F. S. Grundtvig, København.

Balling, Jakob L. (1993), "Grundtvig, Dante, Milton, and the Problem of European Continuity" i A. M. Allchin m.fl. (red.), Heritage and Prophecy - Grundtvig and the English-speaking World, Århus, 73-86.

- (1998), "Tradition og modernitet i Nyaars-Morgen" i Dansk Teologisk Tidsskrift 2, København, 120-132.

- (1999), "Den kristne digters frihed" i Transfiguration 1, København, 21-31.

Frye, Northrop (1982), The Great Code, New York.

Holm, Anders (2001), Historie og Efterklang - En studie i N. F. S. Grundtvigs tidsskrift Danne-Virke, Odense.

Lundgreen-Nielsen, Flemming (1983), "Mellem romantik og oplysningstid - Grundtvig i litteraturhistorisk perspektiv" i Jørgen I. Jensen og Erik A. Nielsen (red.), Efterklange - et GrundtvigSeminar, Århus, 93-103.

— (1993), "Grundtvig's Poetics" i A. M. Allchin m.fl. (red.), Heritage and Prophecy - Grundtvig and the English-speaking World, Århus, 87-102.

Schjørring, Jens Holger (1990), Grundtvigs Billedsprog - og den kirkelige anskuelse, Frederiksberg. 
Thodberg, Christian og Thyssen, Anders Pontoppidan (red.) (1983), Grundtvig og grundtvigianismen i nyt lys, Århus.

Toldberg, Helge (1950), Grundtvigs symbolverden, København.

Wigh-Poulsen, Henrik (1993), "Guds Fred og God-Morgen" i Carsten Bach-Nielsen m.fl. (red.), Ordet, Kirken og Kulturen, Århus, 322337.

\section{Noter}

1 Det følgende bygger på min specialeafhandling "Nyaars-Morgen" en teologisk og littercer analyse af N. F. S. Grundtvigs digt. Det Teologiske Fakultet, Århus. 2006. Utrykt. Jeg takker Jens Holger Schjørring og Ulrik Overgaard for relevant vejledning i forbindelse med nærværende afhandling. For supplerende oplysninger og kyndige råd takker jeg Flemming Lundgreen-Nielsen.

2 "En herlig Søndag-Formiddag har du skjænket mig i Dag. I min stille Løvsal her ved Søen har jeg drømt din store, underlige NyaarsmorgenDrøm med dig og hjærtelig glædet mig, ikke alene over de herlige Orgelog Kirkeklokketoner, som klang for mig fra dit Liv og din Sang; men fornemmelig over det nye Liv og det nye store Haab, Gud har vakt i dit Hjærte, om Danmarks Gjenfødelse og om en ny Dag og et nyt velsignet Aar i Guds Rige paa Jorden" (Ingemann i brev til Grundtvig 5. september 1824, Grundtvig 1882, 25).

Jf. i øvrigt Joh 1,5 .

4 Originaltrykket af Nyaars-Morgen har hverken strofenummerering eller romertalsnummerering af de ti sange. Hvert afsnit er blot markeret ved en lang centreret pausestreg. Det er Svend Grundtvig, der (jf. PS V 1883, 153 ) indfører denne praktiske notation, som også følges i Begtrups særudgave i 1901 og i hans US IV fra 1906.

5 "Gud gav mig et poetisk-historisk Øje, hvormed jeg i Herrens Lys skuer ud over det store Kaos, som den menneskelige Virksomhed paa mer og mindre vilde Veje udgjør; jeg ser en vidunderlig Sammenhæng i det hele, men i det meste skimter jeg den kun dunkelt, og mine Læsere skimte tit kun dunkelt, hvad der staar klart for mig, og se da kun idel Mørke, hvor jeg skimter dunkelt" (Grundtvig i brev til Ingemann 4. december 1824, Grundtvig 1882, 48).

6 Gådespejlet er i øvrigt en vigtig metafor i Et Blad af Jyllands RimKrønike.

7 Augustins tredje led er således også en tydelig del af Grundtvigs tænkning. 